\title{
Influence of Cleaning Time in Household Reservoirs on Trihalomethane Formation in Treated Water
}

\author{
Ricardo Andreola1*, Péricles Martim Reche², Gervasio Tono', Graciene de Souza Bido', \\ Daniele Fernanda Felipe ${ }^{1}$, Anny Rosi Mannigel ${ }^{1}$, André Ribeiro da Costa ${ }^{1}$, \\ Gisele Caroline Novakowski ${ }^{3}$, Letycia Lopes Ricardo4, Flavia Helena de Moura Liborio', \\ Stephane Raquel Almeida Velande da Fonseca ${ }^{1}$, Isabela Silva de Oliveira ${ }^{1}$, \\ Giuliano Patrick Rasera1, Thaise Moser Teixeira1
}

\author{
${ }^{1}$ University Center of Maringá (UNICESUMAR), Master in Science, Technology and Food Safety, Maringá, Brazil \\ ${ }^{2}$ State University of Ponta Grossa, Campus Uvaranas, Ponta Grossa, Brazil \\ ${ }^{3}$ State University of Maringá, Maringá, Brazil \\ ${ }^{4}$ Federal University of Paraná, Palotina, Brazil \\ Email: ^ricardo.andreola@unicesumar.edu.br, ^randreola25@uol.com.br
}

How to cite this paper: Andreola, R., Reche, P.M., Tono, G., de Souza Bido, G., Felipe, D.F., Mannigel, A.R., da Costa, A.R., Novakowski, G.C., Ricardo, L.L., de Moura Liborio, F.H., da Fonseca, S.R.A.V., de Oliveira, I.S., Rasera, G.P. and Teixeira, T.M. (2019) Influence of Cleaning Time in Household Reservoirs on Trihalomethane Formation in Treated Water. Journal of Water Resource and Protection, 11, 1389-1397. https://doi.org/10.4236/jwarp.2019.1111080

Received: July 3, 2019

Accepted: November 19, 2019

Published: November 22, 2019

Copyright $\odot 2019$ by author(s) and Scientific Research Publishing Inc. This work is licensed under the Creative Commons Attribution International License (CC BY 4.0).

http://creativecommons.org/licenses/by/4.0/ (c) (i) Open Access

\begin{abstract}
Chlorination is an efficient and low-cost technique in disinfecting water for public water supply. However, during the process, the formation of undesirable by-products called halogen compounds, such as trihalomethanes (THMs), occurs. Some of these compounds are proven to be carcinogenic to laboratory animals. The goal of this study was to investigate the occurrence of THMs in household reservoirs and the influence of cleaning time of these reservoirs on the formation of THMs. A total of 103 households were investigated in the city of Maringá, State of Paraná, Brazil. The residences were classified according to the cleaning time of the reservoir into: up to one year, one to two years and more than two years. Samples were taken from the reservoirs and total trihalomethanes (THMt) were analyzed by gas chromatography (GC-MS), total organic carbon (TOC) by means of a Hach kit for low concentrations and free residual chlorine (CLres) by means of a kit for in loco determination. According to the results, the highest concentrations of THMt were observed in the reservoirs with cleaning time of more than 2 years. However, no amount has exceeded the maximum limit allowed by law. In general, the longer the time for cleaning the reservoir, the greater the degradation of water quality in THMt.
\end{abstract}

\section{Keywords}

Trihalomethanes, Distribution Network, Chlorination, Cancer 


\section{Introduction}

The chlorination process is a very efficient way for water disinfection for public supply, providing among other benefits, the reduction of infant mortality due to enteric diseases [1] [2]. However, there is the disadvantage of forming undesirable products called halogen compounds, such as trihalomethanes (THMs), haloacetic acids, halopicrins, cyanogen chloride, among many others [3] [4].

THMs are small molecules made up of atoms of carbon, hydrogen and elements of $7 \mathrm{~A}$ (chlorine and bromine are the most common). These are compounds that correspond to the substitution of hydrogen atoms in the methane molecule by elements of 7A. The term total trihalomethanes (THMt) is the algebraic sum of four compounds: trichloromethane, bromodichloromethane, dibromochloromethane and tribromomethane [1].

The formation of THMs has a primary relationship with eutrophication of aquatic systems and their increase is related to the concentration of organic matter, precursor source of these compounds. Some studies have shown that eutrophic reservoirs have about $30 \%$ more trihalomethane precursors than noneutrophic ones [5] [6] [7] [8].

Many of the by-products from chlorination, including THMs, are potentially carcinogenic, mutagenic and capable of being bioaccumulated in trophic chains [2] [9] [10] [11]. Experiments in animals have demonstrated the mutagenic and carcinogenic character of THMs, leading to the belief that it may occur in humans [12].

The maximum allowable THM in drinking water varies among different countries. In the United States it is $80 \mu \mathrm{g} / \mathrm{L}$; in the Netherlands, $75 \mu \mathrm{g} / \mathrm{L}$; in Germany, $25 \mu \mathrm{g} / \mathrm{L}$ and in France, $10 \mu \mathrm{g} / \mathrm{L}$ [12]. In Brazil, the limit is set at $100 \mu \mathrm{g} / \mathrm{L}$ for the potability standard [1].

In several parts of the world, there are studies on the occurrence of THMs in treatment plant waters, distribution networks and in water reservoirs [10] [13]-[22]. Nevertheless, few report the occurrence of THMs associated with the cleaning time/residence time of the water in the reservoir [23].

The investigation of THMs at the Water Treatment Station (WTS) in Maringá, State of Paraná, Brazil [24] showed that these compounds were present in all stages of treatment, with a mean concentration of $57 \mu \mathrm{g} / \mathrm{L}$. Thus, the goal of this study was to analyze the occurrence and concentration of THMt and the respective influence of organic matter and free residual chlorine on the formation of these compounds in household reservoirs in the city of Maringá, Brazil.

\section{Material and Methods}

\subsection{Characteristics of Supply throughout the City}

The Sanitation Company of Paraná-SANEPAR responsible for the treatment and distribution of water serves a population of approximately 417,000 inhabitants. Water supplying approximately $87 \%$ of the population comes from treated river water and approximately $13 \%$ of homes are supplied by underground wells 
[24]. The water distribution network of the city of Maringá is structured as distribution rings that surround each city block.

\subsection{Collection of Water Samples in the Study Region}

The study was carried out in household reservoirs (Figure 1) in a region close to the Water Treatment Station. The distribution network is composed of exclusively cast-iron tubing (Figure 2).

In the studied region (Figure 2), in the residences with reservoir, was evaluated the concentration of THMt, total organic carbon and free residual chlorine in relation to the cleaning time of the reservoir. The cleaning time of the reservoir was considered up to one year, more than one year and less than two years and more than two years.

From each house investigated, $200 \mathrm{~mL}$ water from the distribution network were collected at the point of water inlet into the household from the distribution network and $200 \mathrm{~mL}$ water were collected from the household reservoir (Figure 1).

According to studies conducted by USEPA, National Risk Management Laboratory [25], cast iron pipes tend to provide higher increases in THMs compared to PVC pipes.

\subsection{Water Analysis}

Total trihalomethanes (THMt), total organic carbon (TOC) and free residual chlorine (CLres) were analyzed in the water samples collected at the point of water inlet into the residence (from the distribution network) and in the household reservoirs.

For determination of THMt, the samples were collected in triplicate using 40 $\mathrm{mL}$ glass bottles with a screw cap and silicone septum. Upon collection, care was taken to fill the vial completely so as to avoid air bubbles in the sample. In

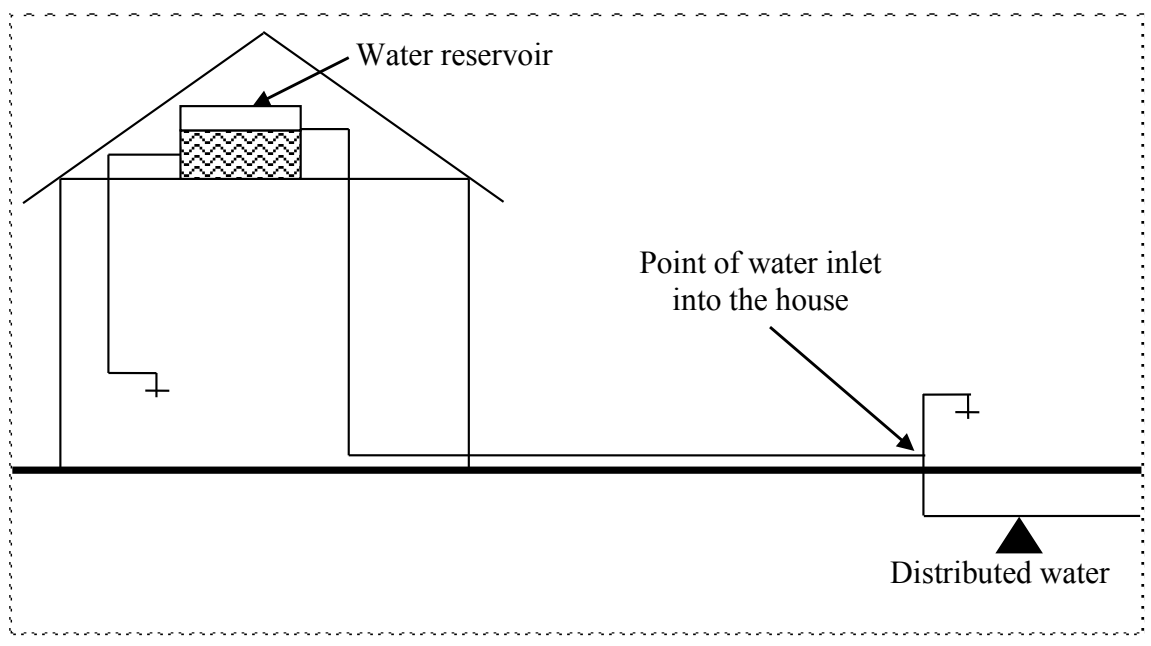

Figure 1. Schematic representation of the household reservoir and point of water inlet into the house. 

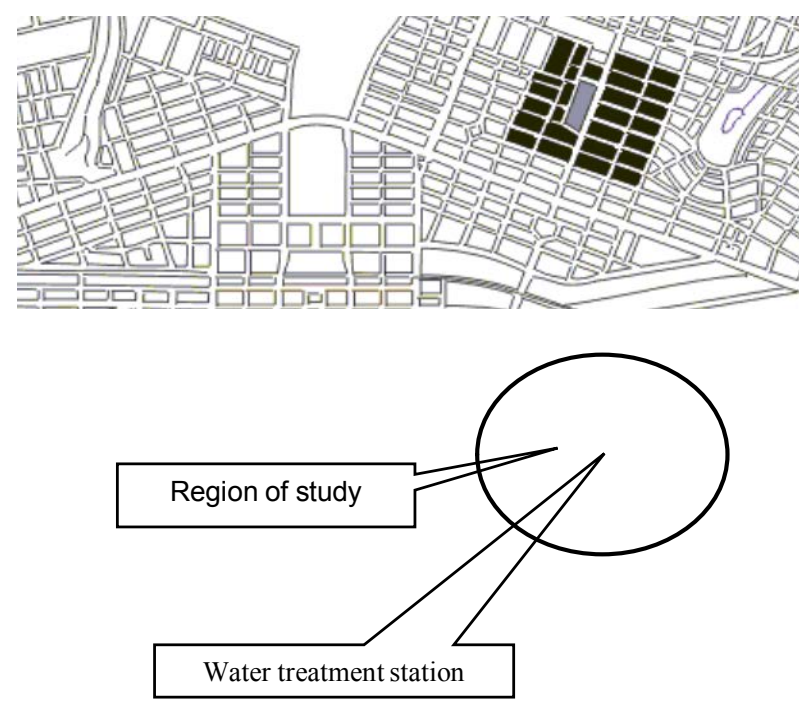

Figure 2. Study area, Maringá, Brazil. Source: Google Maps, 2019.

addition, the vials contained free residual chlorine sequestrant (sodium thiosulfate p.a., $\mathrm{Na}_{2} \mathrm{~S}_{2} \mathrm{O}_{3}$ ) in order to cease the reaction of residual chlorine with the organic matter after taking the sample. After the collection, the vials were stored in thermal boxes.

The THMt analyses were performed using Purge-and Trap Capillary Gas Chromatography (GC), and detection and quantification by mass spectrometry (MS) according to Method 6200-B, Standard Methods of Water and Wastewater [26].

To determine total organic carbon (TOC) the analyses were performed using the Hach kit for low concentrations ( 0.0 to $20.0 \mathrm{mg} / \mathrm{L}$ ), with reading in a UV-VIS spectrophotometer at $600 \mathrm{~nm}$, method 10.129, Manual Hach.

For the determination of residual chlorine (CLres), the DPD (N, $\mathrm{N}$-diethyl-p-phenyl phenylene diamine) colorimetric method for low concentrations $(0.0$ to $2.0 \mathrm{mg} / \mathrm{L})$ was used [23] [27].

\section{Results and Discussion}

Water from 103 households was analyzed according to the cleaning time of the reservoir as up to one year, between one and two years and more than two years (Table 1).

In Figure 3, MC represents the mean THMt of the samples for the point of water inlet into the house and MR is the mean THMt for the reservoirs. In the time axis, 1, 2 and +2 represent the cleaning time of the reservoir in up to one year, one to two years and more than two years, respectively. Higher mean values of THMt were obtained in all studied reservoirs compared to the values in the respective entries of the residences. The largest difference was found for the cleaning time of the reservoir in more than two years. Possibly this value was higher due to the longer time provided for the reaction inside the reservoirs. However, no value found for this class exceeded the maximum allowed by 


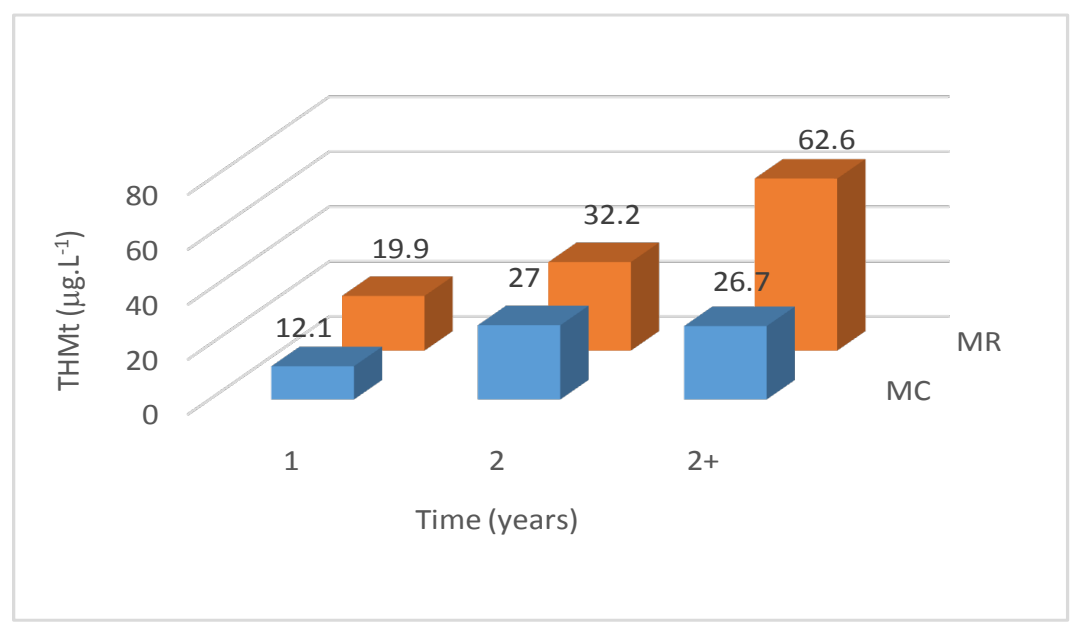

Figure 3. THMt concentration at the point of water inlet into the residence and at the household reservoir.

Table 1. Houses in the study area.

\begin{tabular}{cc}
\hline Cleaning time of the reservoir & Households \\
\hline Up to 1 year & 36 \\
Between 1 and 2 years & 28 \\
More than 2 years & 39 \\
Total & 103 \\
\hline
\end{tabular}

Brazilian legislation, $100 \mu \mathrm{g} \cdot \mathrm{L}^{-1}$, according to Consolidation Ordinance 5 of Ministry of Health [1].

A study [28] found that tap water from different parts of the city had mean THMt values ranging from 48 to $123 \mu \mathrm{g} \cdot \mathrm{L}^{-1}$. In general, European countries do not use household reservoirs, but rather use underground reservoirs of large capacity distributed across the city. The household reservoirs are mainly used in Latin America.

Another study [23] reported an increase from 27 to $46 \mu \mathrm{g} \cdot \mathrm{L}^{-1}$ in THMt (increase of $19 \mu \mathrm{g} \cdot \mathrm{L}^{-1}$ ) in water samples that had a residence time of about $50 \mathrm{~h}$ in storage reservoirs in a building (one underground and one upper). This increase of $19 \mu \mathrm{g} \cdot \mathrm{L}^{-1}$ is high when compared to the increases of THMt at the water inlet of the residence to the reservoir, obtained herein.

Analyses of total organic carbon (Figure 4) show a reduction in TOC concentration from the inlet of water into the residence to the reservoir, in all cases. For all cleaning times of the studied reservoirs, lower TOC concentrations were obtained in the reservoirs when compared to the respective water inlets. This fact possibly indicates that this reduction is related to the reaction of organic matter with the free residual chlorine in the formation of THMs.

Behavior similar to that of TOC was obtained for free residual chlorine analysis (Figure 5). By means of the results of Figure 5 in all reservoirs, lower free residual chlorine values were obtained when compared to the respective water 


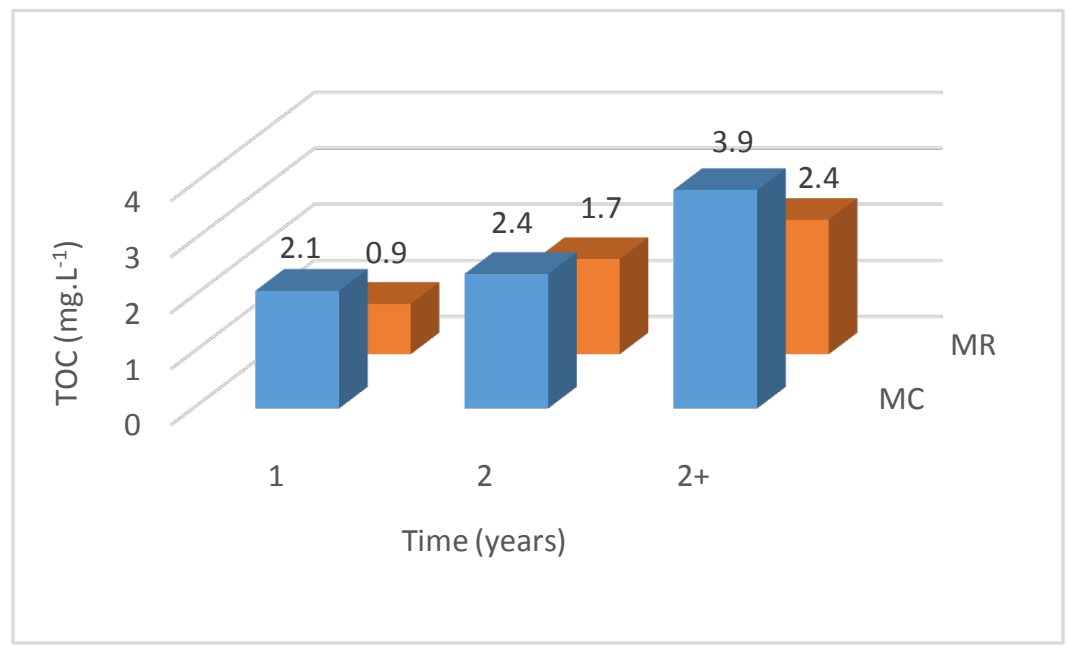

Figure 4. Total organic carbon at the water inlet into the residence and at the household reservoir.

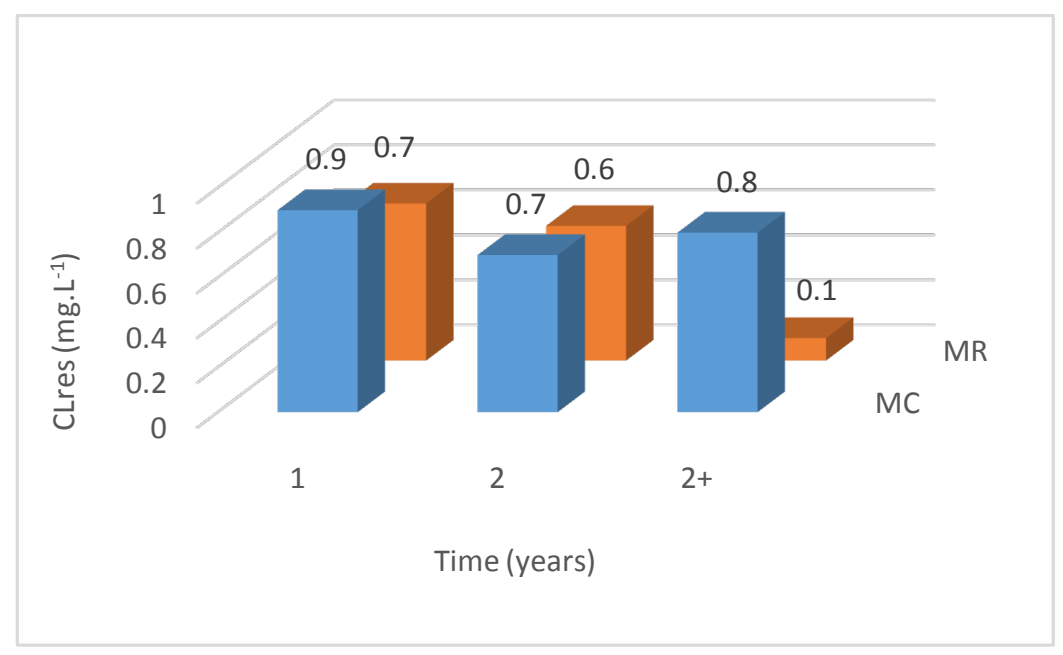

Figure 5. Free residual chlorine at the point of water inlet into the house and at the household reservoir.

inlets. For reservoirs with a cleaning time of more than two years, a mean value of $0.1 \mathrm{mg} \cdot \mathrm{L}^{-1}$ was obtained, which was the lowest mean obtained. This value can be associated with the reaction with organic matter and losses by volatilization in the reservoir.

The legislation in force in Brazil [1] regulates a minimum value of $0.2 \mathrm{mg} \cdot \mathrm{L}^{-1}$ at any point in the distribution network that provides water for entry into the residence. Note that the values at the point of water inlet into the residences are well above $0.2 \mathrm{mg} \cdot \mathrm{L}^{-1}$ (water from the distribution network). If on the one hand, a higher concentration of chlorine results in a better disinfection, on the other, it provides a higher production of THMs.

When analyzed together, the behavior observed in the decrease in TOC values and free residual chlorine from the water inlet into the residence to the reservoir, indicates (considering the losses) that there was an expressive increase in THMt 
production in the reservoirs possibly because of such reductions. This shows that the household reservoir contributes to the degradation of water quality in relation to the formation of THMs. This fact is intrinsically related to the cleaning time of the reservoir. The longer the interval cleaning time is, the greater the water quality degradation is.

\section{Conclusions}

In all THMt analyses, the mean concentration increases from the water inlet into the house to the reservoir. This shows that the reservoir contributes to increasing the concentration of THMt in the water consumed by the user (not only orally but also by contact during bathing). It is observed, therefore, that the household reservoir acts as a reaction medium for the formation of THMs, providing the reaction time sufficient for the concentration to almost double the value found at the point of water inlet into the residence.

The reductions in TOC from the point of water inlet into the house to the reservoir indicate that there is possibly consumption of organic matter in reaction with free residual chlorine, forming THMs. This indicates that, the longer the contact time of organic matter with free residual chlorine is, the higher the concentration of THMs formed will be.

In general, the longer the time elapsed for cleaning the reservoir is, the greater the degradation of water quality considering THMs is.

\section{Conflicts of Interest}

The authors declare no conflicts of interest regarding the publication of this paper.

\section{References}

[1] Brasil (2017) Portaria de Consolidação n. 05 de 28 de setembro de 2017. Consolidação das normas sobre as ações e os serviços de saúde do Sistema Único de Saúde. Diário Oficial da União, Brasília.

[2] Hamester, A., Petry, A.T. and Marques, D.M. (2005) Efeito potencial do gradiente trófico em cascata de reservatórios urbanos na formação de trihalometanos. $23 \mathrm{rd}$ Congresso Brasileiro de Engenharia Sanitária e Ambiental, Campo Grande, 18 September 2005, $10 \mathrm{p}$.

[3] Du, Y., Lu, X.-T., Wu, Q.-Y., Zhang, D.-Y., Zhou, Y.-T., Peng, L. and Hu, H.-Y. ((2017)) Formation and Control of Disinfection Byproducts and Toxicity during Reclaimed Water Chlorination: A Review. Journal of Environmental Sciences, 58 51-63. https://doi.org/10.1016/j.jes.2017.01.013

[4] Tominaga, M.Y. and Mídio, A.F. (1999) Exposição humana a trialometanos presentes em água tratada. Revista de Saúde Pública, 33, 413-421. https://doi.org/10.1590/S0034-89101999000400013

[5] Palmstrom, N.S., Carlson, R.E. and Cooke, G.D. (1992) Potential Links between the Eutrophication of Surface Water Supplies and the Formation of Carcinogens in Drinking Water. In: Gilbert, C.E. and Calabrese, E.J., Eds., Regulation Drinking Water Quality, Lewis Publishers, Ann Arbor, 175-190. 
[6] Pardo, S.D.A. (1996) Avaliação do potencial da formação de trihalometanos em sistemas de abastecimento de água. Dissertação de Mestrado, Universidade Estadual de Campinas, Campinas.

[7] Petry, A.T., Hamester, A. and Marques, D.M. (2005) Análise das diferentes fontes de matéria orgânica precursora em ambiente lótico urbano na formação de trihalometanos. XVI Simpósio Brasileiro de Recursos Hídricos, João Pessoa, 23 August 2005, 8 p.

[8] Padhi, R.K., Subramanian, S., Mohanty, A.K. and Satpathya, K.K. (2019) Comparative Assessment of Chlorine Reactivity and Trihalomethanes Formation Potential of Three Different Water Sources. Journal of Water Process Engineering, 29, Article ID: 100769. https://doi.org/10.1016/j.jwpe.2019.02.009

[9] de Luca, S.J., et al. (2003) Desinfecção de efluentes biologicamente tratados com hipoclorito de sódio: Subprodutos e toxicidade a alevinos de Tilápia do Nilo (Oreochromis niloticus). Relatório Técnico de Pesquisa. PROSAB 3. Tema 2.

[10] Hsu, C.H., Jeng, W.L., Chang, R.M., et al. (2001) Estimation of Potential Lifetime Cancer Risks for Trihalomethanes from Consuming Chlorinated Drinking Water in Taiwan. Environmental Research, 85, 77-82. https://doi.org/10.1006/enrs.2000.4102

[11] Freeman, L.E.B., Cantor, K.P., Baris, D., Nuckols, J.R., Johnson, A., Colt, J.S., Schwenn, M., Ward, M.H., Lubin, J.H., Waddell, R., Monawar Hosain, G., Paulu, C., McCoy, R., Moore, L.E., Huang, A.-T., Rothman, N., Karagas, M.R. and Silverman, D.T. (2019) Bladder Cancer and Water Disinfection By-Product Exposures through Multiple Routes: A Population-Based Case-Control Study (New England, USA). Environmental Health Perspectives, 125, Article ID: 067010. https://doi.org/10.1289/EHP89

[12] USEPA (United States Environmental Protection Agency) (1998) National Primary Drinking Water Regulations: Disinfectants and Disinfection By-Products Rule: Final Rule.

[13] Viana, R.B., Cavalcante, R.M., Braga, F.M.G., Viana, A.B., et al. (2008) Risk Assessment of Trihalomethanes from Tap Water in Fortaleza, Brazil. Environmental Monitoring and Assessment, 151, 317-325. https://doi.org/10.1007/s10661-008-0273-y

[14] Budziak, D. and Carasek, E. (2007) Determination of Trihalomethanes in Drinking Water from Three Different Water Sources in Florianopolis-Brazil Using Purge and Trap and Gas Chromatography. Journal of the Brazilian Chemical Society, 18, 741-747. https://doi.org/10.1590/S0103-50532007000400012

[15] Yamamoto, K., Kakutani, N., Yamamoto, K., Tsuruho, K. and Mori, Y. (2006) Use of a Home Water Filter in the Reduction of Trihalomethanes and Total Organic Halogen in Tap Water: Forty-One Samples from Osaka City and Surrounding Cities of Japan in 1999, 2000, and 2004. Bulletin of Environmental Contamination and Toxicology, 77, 323-330. https://doi.org/10.1007/s00128-006-1069-9

[16] Singer, P.C., Schlesinger, S.A., Nichols, C., Baribeau, H. and Boulos, L. (2005) Formation and Decay of Trihalomethanes and Haloacetic Acids in Full-Scale Drinking Water Distribution Systems: A Case Study. World Water and Environmental Resources Congress, Anchorage, 15-19 May 2005, 12 p. https://doi.org/10.1061/40792(173)123

[17] Rodriguez, M.J., Sérodes, J.B. and Levallóis, P. (2004) Behavior of Trihalomethanes and Haloacetic Acids in a Drinking Water Distribution System. Water Research, 38, 4367-4382. https://doi.org/10.1016/j.watres.2004.08.018 
[18] White, D.M., Garland, D.S., Narr, J., et al. (2003) Natural Organic Matter and DBP Formation Potential in Alaskan Water Supplies. Water Research, 37, 939-947. https://doi.org/10.1016/S0043-1354(02)00425-6

[19] Sérodes, J.B., Rodriguez, M.J., Li, H., et al. (2003) Occurrence of THMs and HAAs in Experimental Chlorinated Waters of the Quebec City Area (Canada). Chemosphere, 51, 253-263. https://doi.org/10.1016/S0045-6535(02)00840-8

[20] Golfinopoulos, S.K., Kostopoulou, M.N. and Lekkas, T.D. (1998) Volatile Halogenated Organics in the Water Supply System in Athens, Greece. Water Research, 32, 1811-1818. https://doi.org/10.1016/S0043-1354(97)00404-1

[21] Garcia-Villanova, R.J., Garcia, C., Alfonso Gomez, J., et al. (1997) Formation, Evolution and Modeling of Trihalomethanes in the Drinking Water of a Town: I. At the Municipal Treatment Utilities. Water Research, 31, 1299-1308.

https://doi.org/10.1016/S0043-1354(96)00335-1

[22] Garcia-Villanova, R.J., Garcia, C., Alfonso Gomez, J., et al. (1997) Formation, Evolution and Modeling of Trihalomethanes in the Drinking Water of a Town: II. In the Distribution System. Water Research, 31, 1405-1413.

https://doi.org/10.1016/S0043-1354(96)00336-3

[23] Yamamoto, K., Kakutani, N., Yamamoto, A. and Mori, Y. (2007) A Case Study on the Effect of Storage of Advanced Treated Water in a Building's Plumbing System on Trihalomethane Levels. Bulletin of Environmental Contamination and Toxicology, 79, 665-669. https://doi.org/10.1007/s00128-007-9307-3

[24] Andreola, R., Gimenes, M.L., Bergamasco, L., Dias Filho, B.P. and Constantino, A.F. (2005) Formação de Trialometanos em uma Estação de Tratamento de Água. Acta Scientiarum. Technology, 27, 133-141. https://doi.org/10.4025/actascitechnol.v27i2.1457

[25] Jeffrey Yang, Y., Impellitteri, C.A., Clark, R.M., Haught, R.C., et al. (2008) World Environmental and Water Resources Congress 2008 Ahupua'a, Hawaii, January 25.

[26] Clesceri, L.S., Greenberg, A.E. and Eaton, A.D. (1998) Standard Methods for the Examination of Water and Wastewater. 20th Edition, APHA, AWWA \& WEF, Washington DC.

[27] Noll, R., Oliveira, I.L. and Pescador, J. (2000) Avaliação de dois Métodos Concorrentes usado na Determinação do cloro em Água Tratada. XXVII Congresso Interamericano de Engenharia Sanitária e Ambiental, Porto Alegre, 3-8 de dezembro 2000, 5 p.

[28] Calderón, J, Capell, C., Centrich, F. and Artazcoz, L. (2002) Subproductos halogenados de la cloración en el agua de consumo público. Gaceta Sanitaria, 16, 241-243. https://doi.org/10.1016/S0213-9111(02)71668-3 